\title{
Szállodai létesítmények robbantások elleni védelmének lehetőségei
}

\section{Defence Possibilities of Hotel Facilities against Explosions (Bombing Attacks) ${ }^{3}$}

A terrorista-támadások során az elkövetök célja a lehetö legnagyobb pusztítás mellett, hogy tettük minél szélesebb körü publicitást kapjon. Ehhez az egyik széleskörüen alkalmazott eszköz a robbanóanyag, amelyet akár rejtetten, akár erőszakos úton, például tehergépjármüvel áttörve juttatnak el a tervezett célponthoz, célpontba. A támadások olyan helyszínekre irányulnak, ahol sokan, sok helyröl érkezve tartózkodnak egy helyen. Az elmúlt évek eseményei bizonyitják, hogy a kedvelt turistacélpontok szállodai létesítményeiben is történtek ilyen merényletek. A tanulmányban e létesítmények védelmi szintjének, fizikai biztonságtechnikai eszközökkel történő fokozásának lehetöségeit foglaljuk össze bizonyítva, hogy a külső esztétikum és a magas hatásfokú védelem ma már kölcsönösen biztositható.

Kulcsszavak: terroristarobbantás, biztonsági távolság, ramming támadás, utcabútor, fizikai akadály, beltéri biztonsági bútor

The goal of the perpetrators in case of a terrorist attack, besides causing as much damage as possible, is to widely publicise their actions. One of the most commonly used tools for this is explosives, which can be delivered to its destination hidden or by the use of force, for example breaking through with a truck. Attacks tend to target locations where a large number of people from various places stay within the same space. Events from the previous years prove that such attacks can occur in hotel facilities popular amongst tourists. In this study we prove that the

Nemzeti Közszolgálati Egyetem Katonai Műszaki Doktori Iskola, a hadtudomány kandidátusa, egyetemi tanár, e-mail: lukacs.laszlo@uni-nke.hu

2 Nemzeti Közszolgálati Egyetem Katonai Műszaki Doktori Iskola, téma- és tantárgyhirdető külsős oktató, e-mail: balogh.zsuzsanna@uni-nke.hu

3 Az V. Turizmus és Biztonság Nemzetközi Tudományos Konferencia-Tanulmánykötet. Pannon Egyetem Nagykanizsa, Körforgásos Gazdaság Egyetemi Központ, 2021. címủ kiadványban megjelent tanulmány másodközlése. 
aesthetics and high efficiency protection can both be ensured by summarising the possibilities of improving the level of defence in such facilities with the use of physical security equipment.

Keywords: terrorist blast, stand-off distance, ramming attack, street furniture, physical obstacle, indoor security furniture

\title{
1. Bevezetés
}

Az elmúlt év áprilisában jelent meg az 1163/2020. (IV. 21.) Kormányhatározat Magyarország Nemzeti Biztonsági Stratégiájáról. A bevezető részben foglaltak szerint:

\begin{abstract}
„Magyarország Nemzeti Biztonsági Stratégiájának célja hazánk jelenlegi biztonsági szintjének megőrzése és erősítése, ennek nyomán pedig az ország további fejlődésének szavatolása egy változékony világban. Ehhez felvázoljuk nemzeti jövőképünket, [...] tárgyaljuk hazánk [...] biztonsági környezetét, valamint [...] azonosítjuk a legfontosabb kihívásokat és az azokra adott válaszainkat, illetve lehetőségeket." Hazánk biztonsági környezetéröl megállapítja: „A kontinensünkön elkövetett terrorcselekmények arra utalnak, hogy a szélsőséges vallási indíttatású terrorizmus egyre növekvő biztonsági kockázatot jelent Európa államai számára." ${ }^{4}$
\end{abstract}

Ebből következően az Alapvető érdekeinket tartalmazó VI. fejezetben többek között ez olvasható:

\begin{abstract}
„Magyarország megkülönböztetett figyelmet fordít a terrorizmus minden formája elleni küzdelemre: a jelenségcsoporttal szembeni leghatározottabb fellépés nemzeti érdekünk. A terrorizmus elleni harc egyszerre épül a terrorcselekmények megelőzésére, a terrorista csoportok és a terrorszervezetek felderítésére és felszámolására, a terrorcselekmények következményeinek kezelésére, a védelmi képességek megerősítésére és a veszélyhelyzetekre való felkészülésre."
\end{abstract}

A VII. fejezetben a kiemelt biztonsági kockázatokkal foglalkozik. Ezen belül a témánk szempontjából fontos megállapítás a következő:

„A változékony globális környezetben számos kihívás, kockázat és fenyegetés irányulhat hazánk vagy szövetségi rendszereink ellen. Magyarország Nemzeti Biztonsági Stratégiájában meghatározott értékeink és adottságaink alapján, az elemzett biztonsági környezetben a következő kihívások nemzeti érdekeinkre gyakorolt hatása a leginkább jelentős:

e) terrorcselekmény elkövetése Magyarországon, illetve magyar állampolgárok vagy magyar érdekeltségek ellen külföldön."6

\footnotetext{
1163/2020. (IV. 21.) Korm. határozat Magyarország Nemzeti Biztonsági Stratégiájáról.

1163/2020. (IV. 21.) Korm. határozat 99.

1163/2020. (IV. 21.) Korm. határozat 124.
} 
Az Átfogó feladatokat és eszközöket felsoroló IX. fejezet a terrorizmus jelentette fenyegetéssel kapcsolatban az alábbiakat tartalmazza:

- „A terrorizmus elleni küzdelemhez nemzeti szinten összehangolt kormányzati tevékenységre, az intézmény- és képességrendszer erősítésére, a hatáskörök összehangolására, horizontális koordinációra, a kockázatelemzési és kezelési, valamint a tájékoztatási módszerek és eljárások egységesítésére van szükség."7

- „A védekezés kiemelt területe a terroristák potenciális célpontjainak védelme, különös tekintettel a lakosságra és hazánk létfontosságú infrastruktúrájára." ${ }^{8}$

A záró rendelkezések a turisztikai szervezetek részére is fontos feladatokat határoz meg:

- „A biztonság egyes részterületeiért felelős szervezetek a jelen dokumentumban adott iránymutatás figyelembevételével alkotják meg és vizsgálják felül saját szakági szabályozóikat. A szakstratégiák megalkotása során a tárcáknak figyelemmel kell lenniük arra, hogy azok álljanak összhangban a Magyarország Nemzeti Biztonsági Stratégiájában foglaltakkal."9

- „A biztonság egyes részterületeiért felelős állami szervezeteknek a Magyarország Nemzeti Biztonsági Stratégiában megfogalmazott iránymutatásokkal összhangban kell megalkotniuk és felülvizsgálniuk a tevékenységükre vonatkozó szakági szabályzókat, különös tekintettel a nemzeti katonai, a rendészeti, a nemzetbiztonsági, a terrorelhárítási, a katasztrófavédelmi, a kiberbiztonsági és a migrációs területekre."10

A tanulmányban a fenti dokumentumban foglaltakhoz kapcsolódóan, a szállodai létesítmények terroristarobbantásokkal kapcsolatos fenyegetettségét és az ellene való védelem egyes lehetőségeit vizsgáljuk meg, különös tekintettel a fizikai védelem eszközeire.

\section{Turisztikai létesítmények elleni terrorista-támadások - tények és következtetések}

A II. Turizmus és Biztonság Nemzetközi Tudományos Konferencián tartott előadásunkban a lehetséges terrorista-támadások jellemzőit és a védekezés lehetőségeit foglaltuk össze röviden. ${ }^{11}$ Egy másik, a kritikus infrastruktúra létesítményeinek robbantások elleni védelmét elemző tanulmány ${ }^{12}$ bevezetőjében, egy 2012-es cikkre hivatkozva az alábbi gondolatok olvashatók:

1163/2020. (IV. 21.) Korm. határozat 147.

1163/2020. (IV. 21.) Korm. határozat 149

1163/2020. (IV. 21.) Korm. határozat 177.

1163/2020. (IV. 21.) Korm. határozat 178.

1 Lukács László - Balogh Zsuzsanna: Turisztikai létesítmények, események robbantásos fenyegetettsége. In Kiglics Norbert (szerk.): II. Turizmus és Biztonság Nemzetközi Tudományos Konferencia Tanulmánykötet. Nagykanizsa, Pannon Egyetem Nagykanizsai Kampusz 2017. 73-84.

12 Lukács László - Balogh Zsuzsanna: A kritikus infrastruktúra létesítményeinek robbantásos cselekmények elleni védelméröl. Honvédségi Szemle, 147. (2019), 3. 85-102. 
„A XIX. századot a nemzeti szabadságharcok, a XX.-at pedig a világháborúk korszakának nevezhetjük. Vajon a XXI. század a robbantásos terrorista merényletek századaként kerül be a történelemkönyvek lapjaiba?"13

A kérdés akár "költőinek” is tekinthető, hiszen elég csak a napi híradásokat olvasni, hallgatni ahhoz, hogy szembesüljünk a rideg valósággal. A tanulmány témájához kötődően, a turizmus fenyegetettségét vizsgálva, sem lehetünk nyugodtak. Az alábbiakban az elmúlt időszak szállodák elleni terrorista-támadásaiból tallózunk.

2004. október 13. Az egyiptomi Tábában az ötcsillagos Hilton szálloda egy része a földdel vált egyenlővé, amikor 200 kg-os pokolgéppel megrakott autó rohant be a szálloda előcsarnokába, és ott felrobbant. A detonáció teljesen szétvetette az épület tízemeletes szárnyát, maga alá temetve a benn lévőket. A támadás utóhatásaként Tábától Sarm es-Sejkig mindenhonnan hazautaztak a turisták. ${ }^{14}$

2008 novemberében merényletsorozat rázta meg Mumbai városát: a Lashkar-e-Taiba nevü pakisztáni iszlamista csoport tíz tagja összesen 12 célpontot támadott meg, vasútállomást, kávézót, egy zsidó kulturális központot és két luxushotelt. Legalább 174 ember veszítette életét, beleértve a támadók közül kilencet, és több mint 300-an sebesültek meg.

2016. január 9. Két helyi fegyveres jutott be egy külföldiekkel teli szállodába az egyiptomi Hurghadában. Öt szállóvendéget megsebesítettek, mielőtt egyiküket agyonlőtték, a másikat pedig ártalmatlanná tették a biztonsági erők. A támadók annak ellenére jutottak be a szállodába, hogy az épület előtt biztonsági őrök posztoltak, a hotelben azonban a rendőröknek sikerült feltartóztatniuk őket.

2016. január 18. Fegyveresek támadták meg a Burkina Fasó-i főváros Splendid nevü luxusszállodáját és a szemközti kávézót. A támadók felgyújtottak, felrobbantottak több, a szálloda előtt parkoló gépkocsit, tüzet nyitottak a hotel melletti kávézó teraszára, majd tűzharcba keveredtek a biztonsági erőkkel. Ezután a szállodába behatolva, ott túszokat ejtettek.

2018. január 21. A kabuli Intercontinental szálloda ellen követtek el fegyveres támadást. A merényletben hat civil, köztük egy külföldi nő vesztette életét. Afganisztán első, 1969-ben épült luxusszállodáját az utóbbi két évtizedben többször is érték terrortámadások, ezért rendkívüli biztonsági intézkedésekkel védték. A mostani akció elkövetői robbantással törtek utat maguknak a szállodába.

2019. január 15. Terrortámadás érte Nairobiban a DusitD2 szállodakomplexumot, amelyben irodák és bankfiókok is vannak. Az összehangolt támadás egy robbantással kezdődött az egyik bankfiók előtt parkoló autónál, majd egy öngyilkos merénylő robbantott a szálloda aulájában.

13 Lukács László: Épületek elleni robbantásos cselekmények és jellemzőik. Müszaki Katonai Közlöny, 22. (2012), Különszám. 4.

14 A kézirat elkészülését követően, ez év februárjában jelent meg egy hír arról, hogy az egyiptomi hatóságok 36 km hosszú biztonsági falat húznak a Sarm es-Sejk-i üdülőkomplexum köré, a terrorista-támadások megelőzésére. Lásd Betonfallal és fémkerítéssel védik az egyiptomi Sarm-es-Sejk turistáit. Infostart, (2021. február 8.). 
2019. április 21. Több mint száz halálos áldozata volt a húsvétvasárnapi robbantásoknak Srí Lankán, több mint 250-en pedig megsebesültek. A támadásokat a fővárosban, Colombóban, illetve az annak környékén lévő szállodáknál, templomoknál követték el. Az egyik colombói szállodában, a Cinnamon Grand Hotelben a pokolgépet az étteremben helyezték el.

2019. december 10. A szomáliai al-Shabaab terrorszervezet iszlamistái megrohamoztak egy szállodát a mogadishui elnöki rezidencia közelében. A támadók a biztonsági erők egyenruháit viselve álcázták magukat. Az AP amerikai hírügynökség a merénylet kapcsán kiemelte, hogy a mostani támadás eltér a szélsőségesek korábbi merényleteitől, amelyekben autókba rejtett pokolgépeket használtak az erősen őrzött létesítmények védelmének áttörésére, a harcosaik rohamát megelőzően. Ebben az esetben azonban csak gyalogosan támadó szélsőségesek voltak, ami új taktikai fogás lehet. Szomáliai tisztségviselők szerint az új biztonsági intézkedések, így a Mogadishuban berendezett ellenőrzőpontok megnehezítik a terroristák dolgát, s gyalogszerrel kénytelenek támadni.

2020. augusztus 16. Szélsőséges iszlamista fegyveresek megtámadtak egy tengerparti szállodát Szomália fővárosában. Legkevesebb tíz ember életét vesztette és többtucatnyian megsebesültek. A rendőrség arról számolt be, hogy délután egy öngyilkos merénylő felrobbantotta magát az Elite Hotel bejáratánál, s ezután a társai megrohanták a négyemeletes épületet.

A támadásokban közös vonás volt, hogy a terroristák olyan létesítményeket támadtak, ahol viszonylag kis helyen sokan tartózkodtak, így rövid idő alatt nagy pusztítást tudtak okozni. Az első csapást robbanóanyag-töltet (töltetek) robbantásával mérték, majd a kialakuló káoszt kihasználva, lőfegyverekkel fokozták a pusztítást.

Hogyan lehet megakadályozni az ilyen típusú támadásokat? Minden robbanóanyaggal elkövetett merénylet elhárításánál az első szabály: a töltet nem juthat be a létesítménybe. Korábbi konferencia-előadásunkban már bemutattuk azokat a korszerű csomagvizsgáló röntgeneket és személyvizsgáló szkennereket, amelyekkel ezek felderíthetők, kiszürhetők. ${ }^{15}$ De mit lehet tenni a gépjárművel támadó öngyilkos merénylővel? Hogy lehet egy szálloda a vendégek számára külsőleg vonzó építmény, egy ilyen támadással szemben mégis biztos védelmet nyújtó „erőd"? Tovább menve: ha mégis bejut egy robbanómellényt viselő merénylő, a belső közös terek kialakításával, speciális berend ezésével csökkenthető-e a robbanás okozta pusztítás hatása? A következőkben ezt mutatjuk be.

\section{Az erőszakos gépjármü-behatolás fizikai akadályai és a beltéri robbanás elleni védelem lehetőségei}

A szállodáknak, mint minden közintézménynek, jól azonosíthatónak kell lennie, esztétikus megjelenésével ki kell hogy tűnjön az épített környezetből. Ezt legtöbbször nagy üvegfelületek alkalmazásával érik el az építészek, ami nyíltságot, természetes megvilágítást biztosít a lobby területén. Ugyanakkor ez a megoldás a biztonság szempontjából nagymértékben

15 Lukács-Balogh (2017): i. m. 
sebezhetővé teszi az épületet. Egy robbantással elkövetett merénylet esetén az üveg nagyon veszélyes építőanyag, szétrepülő szilánkjai - a töltet mennyiségének függvényében - akár több száz méteren is halálos sérülést okozhatnak. ${ }^{16}$ Amennyiben a robbanóanyagot az ugyancsak mostanában „népszerü” ramming-technikával, azaz a nagy sebességgel tömegbe, épületbe száguldó gépjármübe helyezik el, ez több száz kilogramm TNT erejű is lehet. A már meglévő épületek védelmi szintjének növelésére vannak utólagosan alkalmazható megoldások. Ugyanakkor fontos lenne az ilyen támadások elleni védelemre már a szállodák építésekor, telepítésekor gondolni. Ez sajnos még nem jellemző a hazai gyakorlatban. ${ }^{17}$

Amikor olyan helyen épül egy új létesítmény, ahol a telekméret ezt lehetővé teszi, akkor a robbantások hatása elleni védelem szempontjából is optimálisan lehet kialakítani azt. Nagyobb problémát okoz a megfelelő távolságtartás („stand-off distance” biztosítása) a már meglévő, sűrűn beépített területen elhelyezkedő szállodaépületeknél. Ilyen esetekre is vannak utólagos megerősítési megoldások, de a mechanikai védelem kialakítása jóval korlátozottabb, mint az úgynevezett zöldmezős beruházások esetén. ${ }^{18}$

Az alapelv, hogy megakadályozzuk a robbanóanyag bejutását az épületbe, vagy akár azt, hogy egy, az épület közelében parkoló gépjárműbe rejthessék. Ezért a parkolók kijelölését jól át kell gondolni: amennyiben lehetséges, akkor az épület egy kevésbé üvegezett homlokzatának oldalán ajánlott azokat kialakítani.

Már a közútcsatlakozásnál való lehajtónál is az erőszakos behatolásnak ellenálló sorompót célszerű elhelyezni, ahol például a szobafoglaláshoz kapott kóddal azonosíthatja magát a vendég, kizárva ezzel a jogosulatlan belépéseket a területre. Az alábbi ábrán egy beépített környezetben lévő épület elhelyezkedése látszik, ami kellő védelmet nyújt a robbantásos támadás ellen. A szomszédos épülettől, illetve amennyiben ez lehetséges, minden irányban ajánlott a minimum 30 m-es távolságot tartani. Az ellenőrzött terület bejárat utáni útszakasz vezetése nem egyenes, hanem több kanyarral kialakított, megakadályozva, hogy az épület felé tartó autó felgyorsulhasson és becsapódjon az épületbe. A vendégparkolót a telken kívül helyezték el, ugyancsak a fentebb már említett okok miatt.

16 Balogh Zsuzsanna: Üveg az építészetben, a terrorista robbantások tükrében. Müszaki Katonai Közlöny, 20. (2010), 1-4. 257-271.

17 Balogh Zsuzsanna-Szabó Lajos: A „RAMMING”, azaz a tömegbehajtás módszerével elkövetett terrortámadások jelensége és az ellenük való védekezés lehetőségei. Felderítő Szemle, 17. (2018), 4. 140-159.

18 Balogh Zsuzsanna: Tisztes távolság - optimális védőtávolság robbantásos támadások esetén. Repüléstudományi Közlemények, 24. (2012), Különszám. 380-386. 


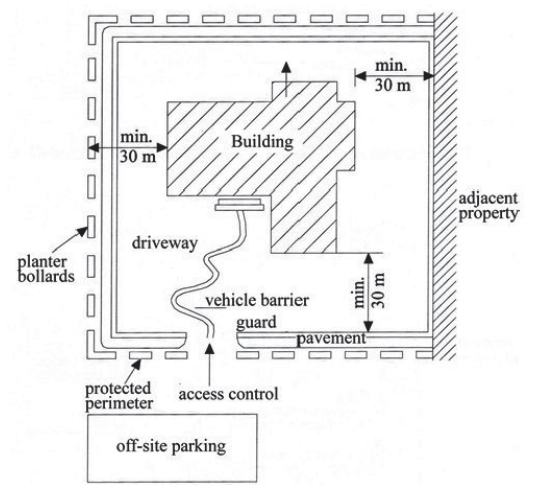

1. ábra. Sematikus épületelhelyezés robbantás elleni védelem biztosítására

Forrás: Zeynep Koccaz - Fatih Sutcu - Necdet Torunbalci: Architectural and Structural Design for Blast Resistant Buildings. The $14^{\text {th }}$ World Conference on Earthquake Engineering, October 12-17, Beijing, China. 2008. 5. ábra

A telek körüli járdát nagyobb (speciális) növényládákkal, esetleg oszlopokkal, egyéb térbútorokkal lehet kiépíteni. A főbejáratok előtti nagyobb virágládák, rusztikus nagy méretű kövek, szobornak látszó tárgyak is szolgálhatnak a védelem eszközeként. Ma már rengeteg különféle, nagyon esztétikus kivitelű behatolást megakadályozó oszlopakadály létezik a biztonságtechnikai elemek tárházában. Ugyancsak kellemes környezetet és észrevétlen biztonságot nyújtanak az utcabútorok, amelyek padok, szeméttárolók, kandeláberek formájában jelennek meg. Ezek alapja mindenkor nagy szilárdságú acél és/vagy vasbeton szerkezet, amelyet megfelelő burkolattal „álcáznak”.

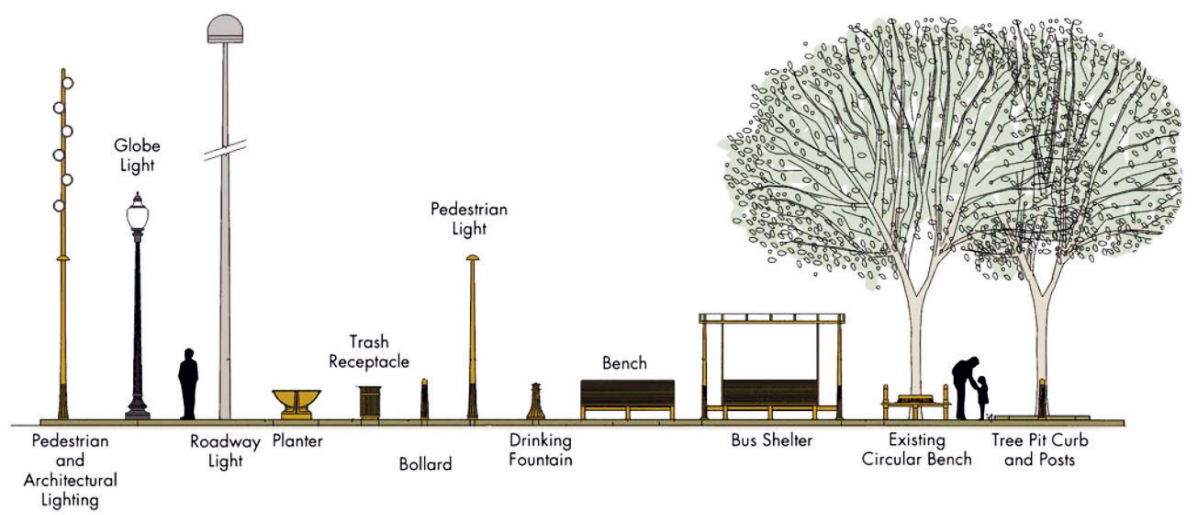

2. ábra. Utcabútorok a biztonsági távolságok kialakítására

Forrás: FEMA: Reference Manual to Mitigate Potential Terrorist Attacks Against Buildings. Federal Emergency Management Agency, US Government, (2003. december). 2-4. ábra

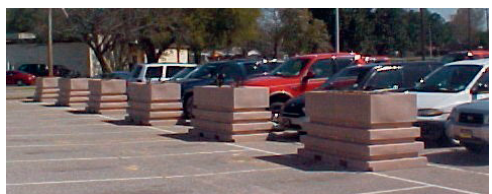

3. ábra. Virágláda barikádelemek

Forrás: http://perimetersecurityproducts.com/products/8-urban-terrorism-safety-barricade/ 
Mit lehet tenni akkor, ha az épület olyan belvárosi területen fekszik, ahol utólag már nem biztosítható a fent említett, robbantások ellen védő biztonsági távolság? A kenyai fővárosban lévő amerikai nagykövetség ellen végrehajtott 1998-as robbantásos merénylet bizonyítja, hogy egy közvetlen utcai kapcsolattal rendelkező létesítmény esetén hiába építünk biztonsági kerítést és kaput, szervezünk az erőszakos behatolástól is védő őrséget. A kapu előtt megállított tehergépjárművön felrobbantott, mintegy 3 tonnás bomba súlyos károkat okozott a környező épületekben, több mint 200 halálos áldozatot követelt, és négyezren sérültek meg (4. ábra). ${ }^{19}$

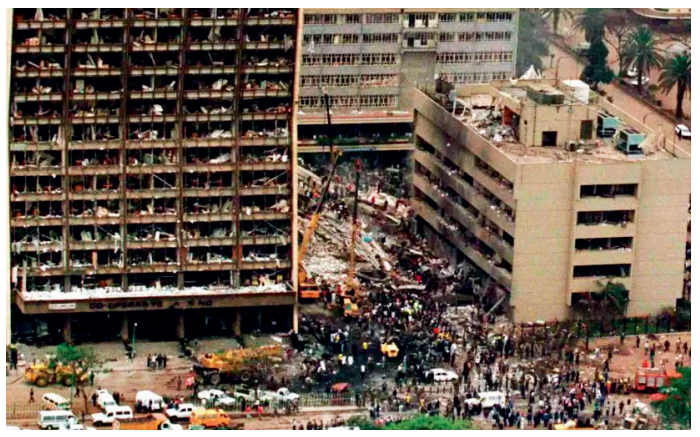

4. ábra. Az amerikai nagykövetség elleni robbantásos merénylet - Nairobi, 1998.

Forrás: Tara Kavaler: The Forgotten Al-Qaeda Victims of the American Embassy Bombings. The Jerusalem Post, 2019. augusztus 6 .

A védelem szempontjából kedvezőtlen adottságok ellenére ebben az esetben sem kell lemondani az ilyen típusú merényletek elleni védekezésről. A hotel főbejárata előtt, vagy akár a biztonságos távolság határán elhelyezhetők olyan oszlopok, amelyek süllyeszthető kialakítása lehetővé teszi az erőszakos behatolás elleni védelmet, ugyanakkor azt leengedve az érkező szállóvendég közelebb hozhatja csomagjait az épülethez. Az épülettel párhuzamosan kialakított rámpán a bejelentkezés előtt pár percre megállhat a járművel a vendég, vagy esetleg ez kiváltható, ha az épület bejáratához még mindig viszonylag közeli parkolóhelyekhez csomagszállító állványt gurítva segíti a személyzet a beköltözést.

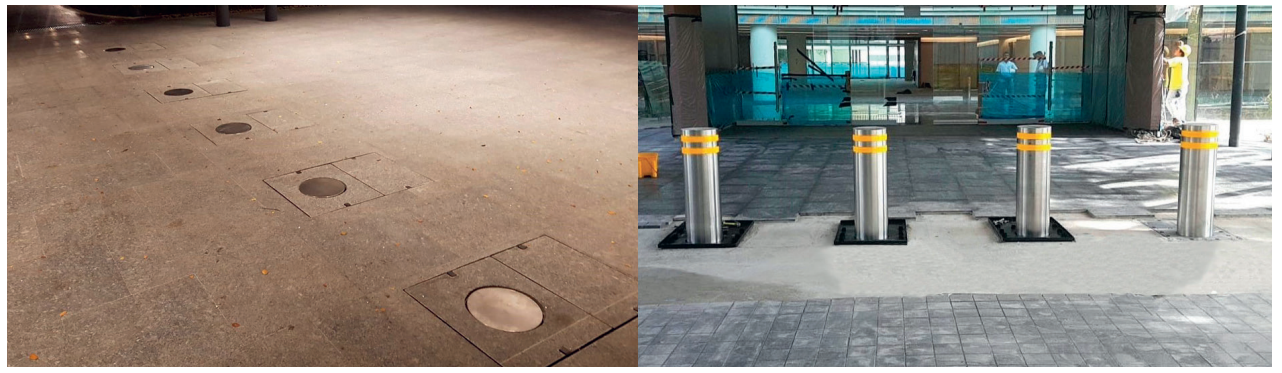

5. ábra. Süllyeszthető oszlopok a bejárat előtt

Forrás: www.heald.uk.com/products/hostile-vehicle-mitigation/bollards/evo-bollard/

19 Lukács László - Balogh Zsuzsanna: Bombatámadás az USA nagykövetség ellen -Nairobi, 1998. augusztus 07. Müszaki Katonai Közlöny, 23. (2013), 2. 159-178. 
Azokon a helyeken, ahol jelentősek a telekárak, a tervezők a költségcsökkentés érdekében a vendégek számára szolgáló gépjármüparkolókat az épületek alatti szinte(ke)n alakítják ki. Ez kényelmes a vendégek számára, hiszen egy belső lifttel a lobbyba, esetleg a szobájukba is feljuthatnak csomagjaikkal. Ugyanakkor rendkívül veszélyes is, hiszen a parkoló személyautókba is elhelyezhető körülbelül 200 kilogrammnyi robbanóanyag. ${ }^{20}$ Ezért sem ajánlott a vonatkozó szakirodalmak, szabványok szerint a felszín alatti garázsok kialakítása. ${ }^{21}$ Ezeket a szabványokat folyamatosan fejlesztik, a bekövetkezett cselekmények elemzésének tapasztalatai alapján. ${ }^{22}$ Azonban, ha semmilyen módon nem kínálkozik más megoldás, a mélygarázsok beléptetésénél rendkívül szigorúan kell eljárni. Nemcsak rendszámfelismerő, illetve zárt láncú TV-hálózat kell, hogy figyelje az autókat, hanem tanácsos egyéb robbanóanyag-detektorokat, esetleg erre képzett keresőkutyákat alkalmazni. Ez utóbbiak jó szolgálatot tehetnek akkor is, ha nem kell folyamatosan magas biztonsági szintet biztosítanunk a szállodának, ugyanakkor egy-egy kiemelt rendezvény vagy VIP-vendég ott-tartózkodása indokolttá teszi ezt.

A vendégparkolókat és a dolgozói/beszállítói parkolót mindenkor el kell különítenünk. A parkolók lezárása történhet sorompóval, vagy akár oszlopokkal. Ezek az elemek bármikor elláthatók rendszámfelismerő, és ezáltal automatikus működést biztosító rendszerrel.

A rendszeres beszállítók (élelemiszer, mosoda stb.) beléptetésének is ellenőrzötten (sorompóval megerősített bejáraton, vagy csúszó/nyíló kapun történő áthaladást követően) kell történnie, amit minden esetben átvizsgálás előz meg. A statisztika azt mutatja, hogy a beszállítókon keresztül gyakran próbálnak robbanóanyagot, -szerkezetet bejuttatni az épületekbe. Ezért nemcsak a szállítóleveleik, egyéb okmányaik rutinszerü ellenőrzése fontos, hanem a gépjárműé is, hiszen a gépjárművezető tudta nélkül is bárki elhelyezhet egy robbanószerkezetet, amelyet aztán távirányítással vagy időzítővel müködésbe léptet. Kiemelt biztonsági igény esetén a teherautók átvilágítása (például Heimann mobil mágneskapuk telepítésével) vagy tetejüknek átvizsgálása (egy mobil létra segítségével) is hasznos lehet.

A középületekre jellemzően a légies, nyitott tér miatt a nagyméretü üvegtáblák használata elterjedt az építészeti eszközök terén. Ezek hiába készülnek ma már valamilyen speciális edzett üvegből, a robbanásra nem méretezettek, hiszen ez nem követelmény a tervezők számára. Akár kifelé, akár a belső térbe berobbanó üvegezett szerkezetek vagy az üvegszilánkok miatt, vagy a nem megfelelő tokhoz való rögzítés miatt okozhatnak súlyos baleseteket. Ezen üvegtáblák megfogására is vannak már kidolgozott módszerek, technológiák.

A lobbyba lépve speciálisan kialakított, megerősített bútorokat helyezhetünk el. Az amerikai Amulet Protective Technologies Inc. például lövés- és robbanásálló szállodai és repülőtéri bútorokat gyárt. Ilyenek a nagy üvegfelületek előtt elhelyezett repeszálló ülőgarnitúrák vagy recepciós pultok. A legtöbb szállodában ma már biztosítanak munkaállomást is, ahol egy

20 A World Trade Center ellen 1993 februárjában, az északi torony alatti garázsban egy kb. 680 kg robbanóanyaggal megrakott kisbusszal követtek el támadást. A robbanás következtében kb. 30 méteres kráter keletkezett, és 6 ember életét vesztette.

21 Department of Defense: UFC 4-010-01, Unified Facilities Criteria (UFC) DoD Minimum Antiterrorism Standards for Buildings (9 February 2012).

22 Balogh Zsuzsanna: Az USA védelmi minisztérium által kiadott, épületek minimálisan kialakítandó terrorizmus elleni védelmének szabványa - egységes létesítményi előírások. Müszaki Katonai Közlöny, 23. (2013), 2. 47-63. 
internetcsatlakozással a vendég saját laptopját üzemeltetheti, nyomtathatja előadása anyagát vagy akár repülőjegyét. Az ilyen célokra kialakított boxoknál jó szolgálatot tehet az ugyancsak ballisztikai válaszfal alkalmazása, így a robbanás esetén berepülő üvegszilánkoktól, törmelékektől megvédi az asztal mögött ülöt.

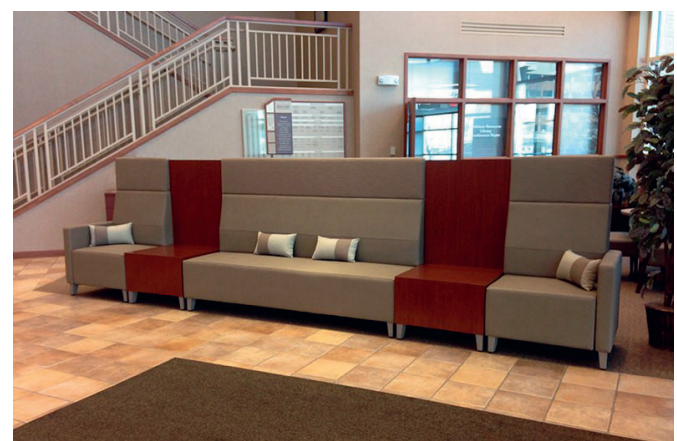

6. ábra. Amulet biztonsági ülöbútor

Forrás: www.amuletbb.com/amulet-in-structures.html

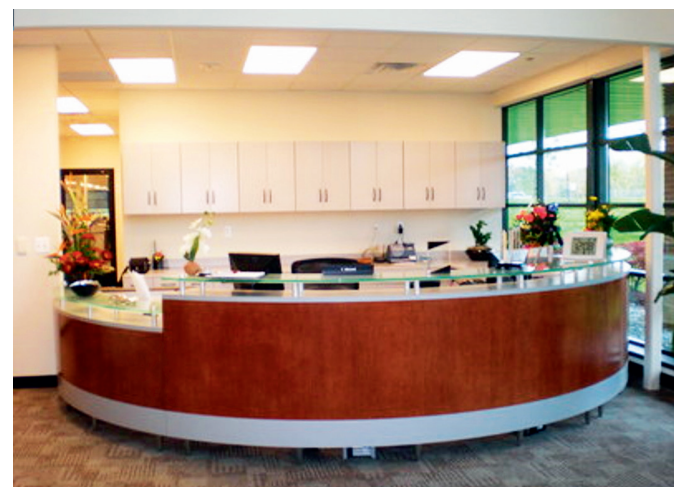

7. ábra. Amulet biztonsági recepciós pult

Forrás: www.amuletbb.com/amulet-in-structures.html

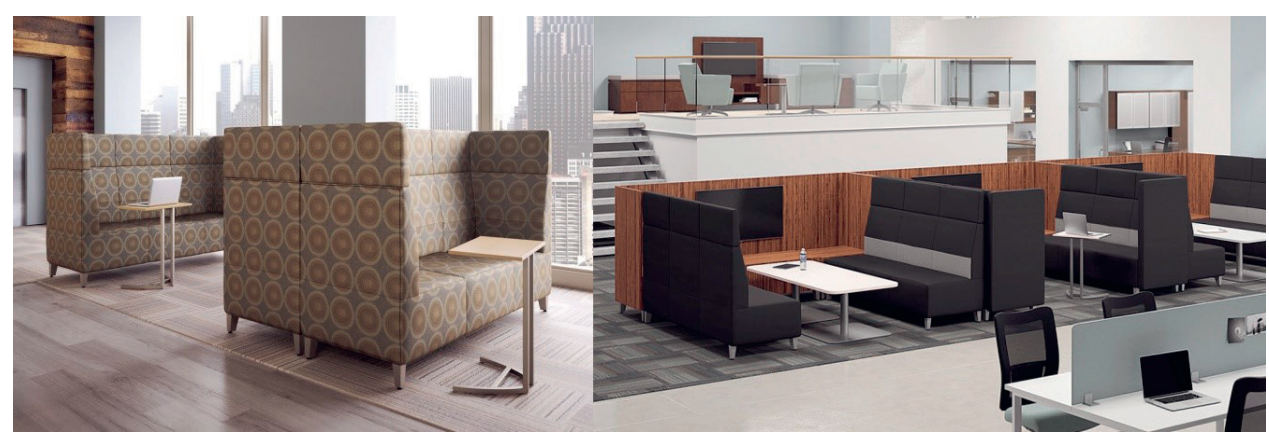

8. ábra. Amulet biztonsági munkaállomás

Forrás: www.amuletbb.com/amulet-in-structures.html 
Ugyancsak jó szolgálatot tehetnek a mobil biztonsági panelek, de akár előadói pultok is, ha a szálloda általában nem igényel kiemelt biztonsági szintet, de elvétve olyan rendezvények helyszíne, amikor ezeket a paravánokat fel lehet állítani, dekorációval ellátva észrevehetetlenül részeivé válnak a védelemnek.
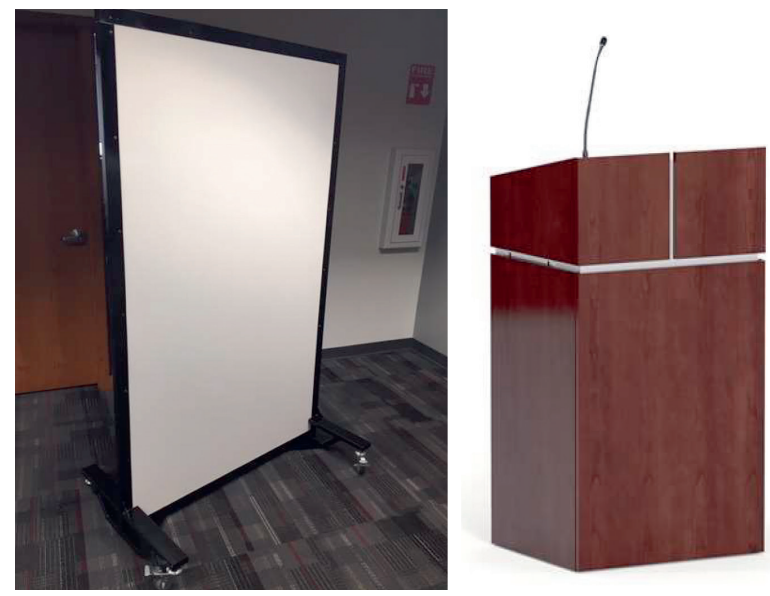

9. ábra: Amulet biztonsági panel és előadópult

Forrás: www.amuletbb.com/amulet-in-structures.html

A lobby belső terét is el lehet látni olyan robbanási lökőhullámokat elnyelő panelekkel, ${ }^{23}$ elemekkel, amelyek egy esetlegesen bekövetkező támadás esetén csökkentik a károkat, a repeszhatásokat, és ezzel emberéletet is menthetnek.

Az erőszakos gépjárműves behatolás ellen védő fizikai akadályok széles palettájával találkozhat a különböző internetes oldalakon biztonsági rendszert tervező szakember. De mennyire hatékony ezek közül az egyik vagy a másik? Mi alapján döntsön a választás során? A legtöbb biztonságtechnikai eszközhöz hasonlóan (tekintsük akár a legegyszerübbeket, például a zárakat, lakatokat) a gépjárművel végrehajtott támadások ellen védő eszközök, berendezések minősítéséről is találunk útmutatót, például az amerikai Védelmi Minisztérium ezzel kapcsolatban kiadott, folyamatosan frissülő adatbázisát. ${ }^{24}$

\section{Befejezés}

A „terror" szó eredeti angol jelentése szerint rémület, rettegés, borzalom, iszony kiváltása a lakosság körében. A fegyveres támadás, robbantás vagy egy sokaságba rohanó tehergépjármű által okozott tényleges veszteségeknél is nagyobb gondot jelent az annak nyomán eluralkodó

23 Ilyenek például a habosított alumínium (Alusion), vagy perlit őrlemény és műgyanta keverékéből készült panelek (TABREShield).

24 Department of Defense: DoD Anti-Ram Vehicle Barriers List. Omaha, Nebraska, USA, US Army Corps of Engineers, Protective Design Center, (November 2019). 
széles körü bizonytalanság, félelem. A fent bemutatott merényletek után kiürültek a térség szállodái, a vendégek elhagyták az üdülőhelyeket, és még évekkel később is érezhető volt a merényletek negatív hatása a látogatóforgalmon.

A terroristamerényletek ma már országoktól és földrészektöl függetlenül jelennek meg, az alkalmazott módszerek is nagyon változatosak. Az egyik leggyakoribb elkövetési módszerré a robbantásos cselekmények váltak. Ezen belül a sokak által látogatott létesítmények, események kiemelt célpontnak számítanak, így a szállodák is „puha célpontok”, ahogy egy tanulmány szerzői fogalmaznak. ${ }^{25}$

Írásunkban azokat a fizikai védelmi eszközöket, berendezéseket próbáltuk bemutatni, amelyekkel - akár a szállodaiparban is - megelőzhetők a gépjármüvel végrehajtott öngyilkos merényletek, illetve csökkenthetők a létesítmények belsejében bekövetkező robbanás hatásai.

Megéri-e a pénzét a terrorelhárítás? - teszi fel a kérdést Bjørn Lomborg, a NATO Review 2008. évi 4. számában. Az általa akkor megfogalmazottak ma is elgondolkodtatók:

„A globális terrorizmus olcsó, csekély emberigényű, a világ figyelmét felkelti és lehetőséget ad a gyengének arra, hogy megrémissze az erőseket. [...] A fejlett világ a fundamentalista iszlám terrorizmus fenyegetésére reagálva kulcsfontosságú célpontjai körül egyre nagyobb, egyre erőteljesebb védelmet épít ki. Egyre nehezebb bejutni a repülőterekre és nagykövetségekre, a legfontosabb látványosságokat is elzárták a potenciális robbantók elől.

2001 óta a világ körülbelül 70 milliárd dollárt költött megnövelt belbiztonsági intézkedésekre. Amint az várható volt ez körülbelül 34\%-kal csökkentette a transznacionális támadások számát. Azonban a terroristák évente átlagosan így is 67-tel több halottat hagytak maguk mögött.

A halottak számának növekedése azért következett be, mert a terroristák racionálisan reagálnak az egyre növekvő biztonsági intézkedések eredményeként létrejött magasabb kockázatra. Olyan tervekre koncentrálnak, amelyek még nagyobb pusztítást okozhatnak.

A kormányok intézkedése annak érdekében, hogy egy helyszínt megvédjenek, egész egyszerủen arra ösztökéli a terroristákat, hogy másik célpontot válasszanak.

Az USA nagykövetségeinek megerösítése az évtized során ugyancsak oda vezetett, hogy több gyilkosságot és támadást követnek el követségi dolgozók ellen, nem biztosított helyszíneken. A tisztviselők védelmére tett intézkedéseknek betudhatóan egyre több támadás éri az üzletembereket és turistákat, mint például a 2005-ös támadások Balin.

A terrortámadások mindig is egyértelmű és olcsó módszer lehetnek az olyan csoportok számára, akik pánikot és kétségbeesést akarnak okozni."26

25 Lippai Zsolt - Thieme-Eső Milán: A szállodák, mint „puha célpontok”. In Csaba Zágon - Szabó Andrea (szerk.): Közös kihívások - egykor és most. Tanulmánykötet. Budapest, Magyar Rendészettudományi Társaság Vámés Pénzügyőri Tagozat, 2020. 160-183.

26 Bjørn Lomborg: Is counterterrorism good value for money? NATO Review, 2008. április 8. 
A 1163/2020. számú kormányhatározatban a Kormány felhívja a feladat- és hatáskörrel rendelkező minisztereket, hogy az 1. mellékletben foglalt, Magyarország Nemzeti Biztonsági Stratégiája Biztonságos Magyarország egy változékony világban elnevezésű stratégiai dokumentum végrehajtását szolgáló ágazati stratégiai dokumentumokat vizsgálják felül, illetve készítsék el. Felelősek: a feladat- és hatáskörrel rendelkező miniszterek. A határidő: 2020. december 31. volt.

Feltehetően már ennek keretében adták ki a 383/2020. (VIII. 7.) Korm. rendeletet a szálláshelyszolgáltatási tevékenység folytatásához kapcsolódó egyes kormányrendeletek módosításáról. Ebben a szálláshely-szolgáltatók részére egy informatikai program kötelező használatát rendelik el, amely okmányolvasóval kialakított kapcsolattal rendelkezik, és amely a Nemzeti Turisztikai Adatszolgáltató Központ, valamint egy tárhely számára adatok továbbítására alkalmas. A szállásadó a vendégek Turizmus tv. 9/H. § (1) bekezdése szerinti adatait köteles rögzíteni a szálláshelykezelő szoftver okmányolvasó részén keresztül, azokat pedig, amelyeknél ez nem lehetséges, manuális adatbevitel útján rögzíti a szoftverben. Ez egy bekövetkezett büncselekmény esetén hasznos adatokkal szolgálhat egy utólagos nyomozás esetén, de a fent jelölt cselekmények megelőzése, elkerülése szempontjából vizsgálva, például egy öngyilkos merénylőt nem fog elrettenteni.

Magyarországon a közelmúltban számos nagy nemzetközi rendezvényt (atlétikai világbajnokság, Nemzetközi Eucharisztikus Kongresszus, Nemzetközi Vadászati és Természeti Kiállítás) bonyolítottak le. A helyszínek terrorcselekményekkel szembeni biztonságát a 2017. évi budapesti úszó-világbajnoksághoz hasonlóan szervezték meg a rendezők. Érdekes lenne annak a kérdésnek a vizsgálata, hogy a Nemzeti Biztonsági Stratégiában foglaltakkal összhangban, csak a Kormány által az elmúlt időszakban juttatott turisztikai támogatásokon belül, akár a Kisfaludy Pályázat keretében mennyit fordítottak, egyáltalán fordítottak-e a szállodák üzemeltetői, a terrorizmus elleni biztonságuk fokozására?

\section{Felhasznált irodalom}

Balogh Zsuzsanna: Üveg az építészetben, a terrorista robbantások tükrében. Müszaki Katonai Közlöny, 20. (2010), 1-4. 257-271.

Balogh Zsuzsanna: Tisztes távolság - optimális védőtávolság robbantásos támadások esetén. Repüléstudományi Közlemények, 24. (2012), Különszám. 380-386. Online: https://doi.org/10.32560/ rk.2012.2.30

Balogh Zsuzsanna: Az USA védelmi minisztérium által kiadott, épületek minimálisan kialakítandó terrorizmus elleni védelmének szabványa - egységes létesítményi előírások. Müszaki Katonai Közlöny, 23. (2013), 2. 47-63. Online: https://doi.org/10.32562/mkk.2013.2.4

Balogh Zsuzsanna - Szabó Lajos: A „RAMMING”, azaz a tömegbehajtás módszerével elkövetett terrortámadások jelensége és az ellenük való védekezés lehetőségei. Felderitő Szemle, 17. (2018), 4. 140-159.

Betonfallal és fémkerítéssel védik az egyiptomi Sarm-es-Sejk turistáit. Infostart, (2021. február 8.). Online: https://infostart.hu/kulfold/2021/02/08/betonfallal-es-femkeritessel-vedik-az-egyiptomi-sarm-es-sejk-turistait 
Department of Defense: DoD Anti-Ram Vehicle Barriers List. Omaha, Nebraska, USA, US Army Corps of Engineers, Protective Design Center, (November 2019). https://usace.contentdm.oclc.org/ digital/collection/p16021coll11/id/3521/

Department of Defense: UFC 4-010-01 Unified Facilities Criteria (UFC) DoD Minimum Antiterrorism Standards for Buildings (9 February 2012). Online: https://des.wa.gov/sites/default/files/public/ documents/Facilities/EAS/Mil\%20Dept\%20DB\%20Project/13295\%20RFP\%20App\%201\%20 E\%20-\%20UFC_4_010_01.pdf

FEMA: Reference Manual to Mitigate Potential Terrorist Attacks Against Buildings. Federal Emergency Management Agency, US Government, (2003. december). Online: www.fema.gov/pdf/plan/ prevent/rms/426/fema426.pdf

Kavaler, Tara: The Forgotten Al-Qaeda Victims of the American Embassy Bombings. The Jerusalem Post, 2019. augusztus 6. Online: www.jpost.com/opinion/the-forgotten-al-qaeda-victims-of-the-american-embassy-bombings-597866

Koccaz, Zeynep - Fatih Sutcu - Necdet Torunbalci: Architectural and Structural Design for Blast Resistant Buildings. The $14^{\text {th }}$ World Conference on Earthquake Engineering, October 12-17, Beijing, China. 2008. Online: www.iitk.ac.in/nicee/wcee/article/14_05-01-0536.PDF

Lippai Zsolt - Thieme-Eső Milán: A szállodák, mint „puha célpontok”. In Csaba Zágon - Szabó Andrea (szerk.): Közös kihívások - egykor és most. Tanulmánykötet. Budapest, Magyar Rendészettudományi Társaság Vám- és Pénzügyőri Tagozat, 2020. 160-183. Online: https://doi.org/10.37372/ mrttvpt.2020.1.9

Lomborg, Bjørn: Is counterterrorism good value for money? NATO Review, (2008. április 8.). Online: www.nato.int/docu/review/articles/2008/04/08/is-counterterrorism-good-value-for-money/ index.html

Lukács László: Épületek elleni robbantásos cselekmények és jellemzőik. Müszaki Katonai Közlöny, 22. (2012), Különszám. 4-13. Online: https://doi.org/10.32562/mkk.2012.4.1

Lukács László - Balogh Zsuzsanna: Bombatámadás az USA nagykövetség ellen -Nairobi, 1998. augusztus 07. Müszaki Katonai Közlöny, 23. (2013), 2. 159-178. Online: https://doi.org/10.32562/ mkk.2013.2.13

Lukács László - Balogh Zsuzsanna: Turisztikai létesítmények, események robbantásos fenyegetettsége. In Kiglics Norbert (szerk.): Il. Turizmus és Biztonság Nemzetközi Tudományos Konferencia Tanulmánykötet. Nagykanizsa, Pannon Egyetem Nagykanizsai Kampusz, 2017. 73-84. Online: https://uni-pen.hu/files/konferencia/2017/Teljes_konf_tanulmanykotet.pdf

Lukács László - Balogh Zsuzsanna: A kritikus infrastruktúra létesítményeinek robbantásos cselekmények elleni védelméröl. Honvédségi Szemle, 147. (2019), 3. 85-102. Online: https://kiadvany. magyarhonvedseg.hu/index.php/honvszemle/article/view/254

http://perimetersecurityproducts.com/products/8-urban-terrorism-safety-barricade/ www.amuletbb.com/amulet-in-structures.html www.heald.uk.com/products/hostile-vehicle-mitigation/bollards/evo-bollard/

\section{Jogi források}

383/2020. (VIII. 7.) Korm. rendelet a szálláshely-szolgáltatási tevékenység folytatásához kapcsolódó egyes kormányrendeletek módosításáról

1163/2020. (IV. 21.) Korm. határozat Magyarország Nemzeti Biztonsági Stratégiájáról 